\title{
A STUDY ON THE PERCEPTION OF STUDENTS IN A HIGHER LEARNING INSTITUTION TOWARDS COLLABORATIVE LEARNING
}

\author{
NoorAileen Ibrahim ${ }^{1}$ \\ Academy of Language Studies, \\ Universiti Teknologi MARA, Perak Branch, \\ Seri Iskandar Campus, 32610, Perak, Malaysia \\ (Email: nooraileen@ perak.uitm.edu.my) \\ NoorLida Daud ${ }^{2}$ \\ Faculty of Art \& Design, \\ Universiti Teknologi MARA, Perak Branch, \\ Seri Iskandar Campus, 32610, Perak, Malaysia \\ (Email: noor9164@perak.uitm.edu.my) \\ Nurul Shima Taharuddin ${ }^{3}$ \\ Faculty of Art \& Design, \\ Universiti Teknologi MARA, Perak Branch, \\ Seri Iskandar Campus, 32610, Perak, Malaysia \\ (Email: nuru1026@perak.uitm.edu.my)
}

Accepted date: 04-11-2018

Published date: 07-07-2019

To cite this document: Ibrahim, N., Daud, N., \& Taharuddin, N. S. (2019). A Study on The Perception of Students in A Higher Learning Institution Towards Collaborative Learning. International Journal of Education, Psychology and Counseling, 4 (31), 46-55.

DOI: $10.35631 /$ IJEPC.431005

\begin{abstract}
In the fast-paces world when we live in today, learners face various problems in the classroom. They are often unmotivated, anxious and helpless because they lack the support and encouragement they need. The purpose of the study is to examine the diploma students' perception of collaborative learning since most students were initially found to be reluctant about group work due to numerous factors. Collaborative Learning (CL) is a pedagogical practice that facilities socialization which leads to academic achievement and has been well documented. A survey through questionnaire is distributed to 100 students from two faculties currently undergoing diploma studies at a local institute of higher learning. Data from the study indicated that the students had positive experiences with CL and a number of them believe that their lecturers helps them to develop a sense of cooperation through CL. The work presented here has implications for future studies of addressing issues related to collaborative learning and might one day help find the appropriate learning style for undergraduates.
\end{abstract}

Keywords: Collaborative Learning, Feedback, Perception, Students 


\section{Introduction}

Nowadays, most students do not prefer to work as a team because of several factors. One of these factors is the rise in the use of gadgets such as the smartphone that has led the younger generation to become more self-absorbed, more anti-social, more reluctant to have face-to-face communication, more individualistic and more unskilled at communicating or co-operating with others. This will have detrimental effects in the future where there will be a rise in individualistic and anti-social individuals. However, some students are more independent and skilled than others and were found to work more efficiently alone. They also find that they can complete the assignments ahead of time and thus, be more productive in the long run. On the other hand, most students that work in a group tend to complain that they are being taken advantage of by the lazy ones that are totally dependent on them to complete any given assignment. The former often feel that they are being bullied or cowed into doing all the work while the latter will share the credit for a job well done. The latter also often expects the former to put in the time and effort in completing the assigned task while they just bask in the glory when the results are out. This creates unnecessary stress on the hardworking ones and in the end, they will shy away from working in a group although it holds numerous benefits. In reality, group work is supposed to promote teamwork and a sense of accomplishment of a job well done. However, the lazy ones do not realise that they are going to face a lot of obstacles in the future especially when they are in the working world because they do not have the commitment and discipline to give their full cooperation in completing a task. The business world or the real working world requires team work from everyone by putting aside petty differences in order to achieve their desired outcome. It is an undeniable fact that great leaders create successful companies but these companies would not have reached the pinnacle of success without dedicated and committed employees that work together tirelessly day and night. There is no secret formula to build strong teams but without committed employees, you cannot build a successful company. IBM, Toyota and Whole Foods are just some of the examples of worldrenowned companies that employ highly effective groups of people that know how to work together (Alsever et al, 2014). This proves that collaboration has never been more important in business because team work is crucial to the success of a company.

According to the State of the Economy and Employment Survey from Adecco Staffing US (2013), which is the pre-eminent workforce management partner for Fortune 500 companies and career advisement expert for American workers, 92\% of senior executives in the U.S acknowledge there is a huge gap in workforce skills. $44 \%$ stated that soft skills such as collaboration, communication, critical thinking, and creativity, as the area with the biggest gap. Nowadays, there has been a shift in emphasis towards the need for soft skills and not just on hard skills or technical abilities (Russo, 2015). This evidently shows that collaboration or team work is an important soft skill that a majority of companies are looking for in potential candidates. Obviously, everyone has his or her own niche or expertise and thus it would require each individual's effort and creativity in completing a task. Feelings of being overwhelmed will also be diminished because no one person is expected to complete such a gargantuan task. Team work is also an important soft skill which is what the majority of companies are looking for in potential candidates. Companies are now looking for candidates that not only have good hard skills but also soft skills. According to Oxford Reference (2016) hard skills are defined as competencies that include literacy, numeracy, fluency in a foreign language, and specific jobrelated technical abilities. These skills are often validated with some form of qualification and relatively easy to measure. However, according to Russo (2015) soft skills comprise attributes and personality traits which relate to emotional intelligence and behaviour. Communication, problem-solving, and flexibility are just some of the examples of soft skills. 
This is the reason that a study on collaborative learning is important as it will help gauge the perception of the younger generation at this type of learning that indirectly helps promote soft skills. According to Ryan (2019) team work is a critical or essential attribute that most employers seek in potential employees. It is hoped that a better awareness of the significance of collaborative learning will also be raised which will help create a more sociable generation that has excellent communication skills, problem solving skills and team work skills.

\section{Literature Review}

The Oxford dictionary (2010) has cited the word collaboration actually originated from mid$19^{\text {th }}$ century Latin collaborare 'work together' that refers to the action of working with someone to produce something. Hacker and Niederhauser (2000), as cited in Ngeow (2004), state that collaboration also includes discussion tasks. The design of instructional strategies must be given careful thought by a teacher to ensure that effective learning takes place. There will be better understanding for the learner because well-thought-out discussion tasks will lead to meaningful interaction as well as promoting creative thought (Ngeow, 2004). When there is collaboration among learners, the learning experience can be enhanced (Brown, 2001). It is believed that collaborative work will reduce dependence on teachers and enhance the learners' ability to participate effectively in conversation. According to Hedge (2000) the collaborative learning method helps to develop the ability of the learner to become effective participants in conversation. Furthermore, being effective participants in conversation is one of the aims of communicative language teaching. This provides additional support that the use of collaborative learning method in the ESL classroom will develop students' communicative abilities.

Collaborative learning is when both learners as well as facilitators actively participate in the learning process and knowledge is created through group discussion. Moreover, collaborative learning is also associated with democratic planning, risk taking and decision making. It also provides benefits to learners as it encourages them to discover their potential and develop their confidence as learners. This is a direct result of sharing knowledge with their peers (Novotny, Seifert \& Werner, 1991). Besides that, the role of facilitator as an authority and source of knowledge is minimised because knowledge is created by the activities and views of the entire group and not by any particular individual (Romer, 1985).

Everyone will lend support to one another when they are working in groups. According to Tinto \& Pusser (2006) by being part of a community, students will receive the academic and social support in learning that they need. The majority of students are unable to cope with the complex learning process by themselves as stated by McCabe (2003), as cited by Wilmer (2008). According to Cabrera, Colbeck \& Terenzini (2001), as cited in Chalmers (2008), students' development such as cognitive and academic development can be deeply affected by the experiences faced by students in the classroom. It is imperative that a classroom environment is not only conducive to learning but will also lead to further academic success for its students. According to Minkler (2002), as cited by Wilmer (2008), one of the reasons collaborative learning is preferred is because it promotes a more active and responsible role on the part of the student. Students will not feel alone and isolated from the rest when they are learning in a group. Students will receive the much needed social support which is more meaningful and interesting when the collaborative learning method is incorporated into their learning experience. According to Stahl, Koschman \& Suthers (2006) this is because learning occurs socially through group interactions like negotiation and sharing of ideas. 
Collaborative learning has already been applied in many classrooms since the late 1980s (Brufee, 2000). There are several important elements involved such as negotiation and shared meaning in the collaborative learning method. It is not simply a case of grouping students to work together. According to Brufee (2000) this particular learning method has been applied in numerous classrooms since the late 1980s. Furthermore Stahl, Koschman \& Suthers (2006) believe that the learning process will be greatly enhanced since learning occurs socially within group interactions.

The collaborative learning approach has been applied in many ways in the present technological advanced era. According to Roberts (2005) computer-supported collaborative learning in higher education that is a shift from the traditional face-to-face group work is one of them. The collaborative learning method is used in another study by Daradoumis \& Marques (2000). A distance education course that is developed and taught in a virtual learning environment was the focus of this particular study. The purpose is to facilitate interaction through the Web among students and also between tutor and students. It was discovered that there was a marked improvement in the study and learning of the subject matter, an increase in interest of the students in the subject matter and also an increase in attitude and social interaction, when collaborative learning was incorporated.

A North Carolina State University study examined changes in advanced undergraduate students' perceptions of pair programming and collaboration (Layman, 2006). Student personality types, learning styles, and other characteristics were the information that were gathered. The results of the study discovered that the majority of students showed a stronger inclination to cooperate with other students, believed that being organised was a direct result of pairing, and believed that pairing also helped them to save time on meeting the deadline of homework assignments. However students who were predominantly reflective learners and introverts disliked the collaborative learning method. Having un-cooperative partners and problems in scheduling meeting times outside the classroom were the primary reasons for disliking pair programming. Moreover, since assertiveness is much needed in face-to face interaction, more passive students may also find it challenging to work in groups. Some disadvantages in the implementation of collaborative learning are risk-taking and the possibility of domination of the group work by some individuals. Nonetheless, having supportive relationships with each other in a classroom has produced optimum results as concluded by one study by Wilmer (2009). Furthermore, being among others and getting support is vital to the development of an individual.

Last but not least, the role of the teacher in the implementation of collaborative learning should not be underestimated. It is vital that the teacher monitor the collaboration level and intervene whenever necessary to elicit collaboration. This is to ensure adequate support is provided to the students in their group collaboration (Abdu, De-Groot \& Drachman, 2012). It is also necessary that the teachers should either explicitly or implicitly teach students the required skills that promote cooperation (Gillies \& Boyle, 2010). In order to ensure the success of collaborative learning, interpersonal and small-group skills are vital and need to be applied by the students.

According to Van Boxtel, Van der Linden \& Kanselaar (2000) when there is active social interaction among the students the elaboration of conceptual knowledge will be stimulated. Moreover, through collaborative learning the students will be able to verbalise their understanding and a more coherent explanation will be the result of this social interaction between the students. Furthermore, when students ask questions and there is an active exchange 
of ideas inevitably it will result in knowledge being actively constructed and reasoning being facilitated (Sonmez, 2003).

\section{Problem Statement}

In a local institute of higher learning in Malaysia, although the syllabus does actively encourage students to cooperate with each other such as in group assignments, projects and also presentations, some students do not like to work in groups. This is mainly because they are often the target of less diligent students who latch onto them because they are the ones who actually do all the work. This study is to investigate the perception of students in a higher learning institution in Malaysia towards Collaborative Learning.

\section{Discussion of the Findings}

The purpose of the study is to examine the diploma students' perception of collaborative learning. A survey through questionnaire is distributed to 100 students currently undergoing diploma studies from two different faculties namely the Faculty of Town Planning \& Architecture and also the Faculty of Art \& Design, at a local institute of higher learning in Malaysia. This study uses convenience sampling because of the ease of selecting the respondents since they are available and easily accessible to the researcher. The survey has 18 items and each part is divided into eliciting students' attitudes towards collaborative learning, role of lecturers and the course syllabus in relation to collaborative learning. The work presented here has implications for future studies of addressing issues related to collaborative learning and might one day help find the appropriate learning style for undergraduates. Below are the findings on the perception of students towards collaborative learning.

Based on Figure 1, the majority of respondents $84 \%$ agree that collaborative learning is an important learning style and that it should be incorporated in every classroom. $67 \%$ of the respondents also agree that they enjoy studying in a group while $46 \%$ are unsure whether they dislike studying alone. In addition, a major portion of the respondents $46 \%$ are unsure whether they can study better alone. The majority or $80 \%$ of the respondents also agree that they feel better knowing they can discuss with their group members. $71 \%$ of the respondents also prefer to work with other students on a classroom project or assignment. $61 \%$ of the respondents agree that only some students give their full cooperation to complete a class project or assignment while only $62 \%$ of respondents agree that most students give their cooperation while $38 \%$ believe that only a few students give their cooperation as shown in Figure 2. Hence, it could be concluded that most students have a favourable view towards collaborative learning, generally believe that they enjoy studying in a group and feel better knowing they can discuss with their group members rather than working alone.

The role of the lecturer is also important in relation to collaborative learning. Based on Figure 3 , most of the respondents $88 \%$ agree that their lecturers help them to develop a sense of cooperation. This is evident when $85 \%$ of the respondents agree that their lecturers encourage them to work in a group in completing class assignments or projects. Nevertheless, $45 \%$ of the respondents are unsure of whether the lecturers should discourage students to work alone on an assignment or project. However, 54\% agree that lecturers should allow students to work in a group on an assignment or project. Thus, the role of the lecturer is crucial in promoting the use of collaborative learning since the majority of the respondents enjoy working together on a classroom project or assignment. Based on Figure 4, 68\% which represents the majority of the respondents agree that course syllabus encourages collaborative learning whereas $32 \%$ are uncertain whether it encourages students to work independently in the classroom. At present, 
the current syllabus does promote collaborative learning because the class projects or assignments are done by group work or pair work.

Khairiyah \& Mimi (2003) stated studies have shown learners will learn better when the learning process is done in a fun yet educational way. This will lead to improved results for the students because active learning has enhanced the level of understanding of the students. A classroom environment that will evoke and retain the interest of learners is one which is conducive and non-threatening. According to Seng (2006) the collaborative learning method can create such an environment where students will not be under pressure and they will be eager to participate in discussions. Students enjoyed working in groups when there are fun and interesting communicative activities in the classroom. The chances of academic success is increased through collaborative learning (Seng, 2006). Collaborative learning has been proven that it will provide a variety of advantages to students. Thus it is safe to deduce it is an effective tool in the classroom and should be implemented as a learning method that will not impede the learning process of the learners but actually facilitate the process.

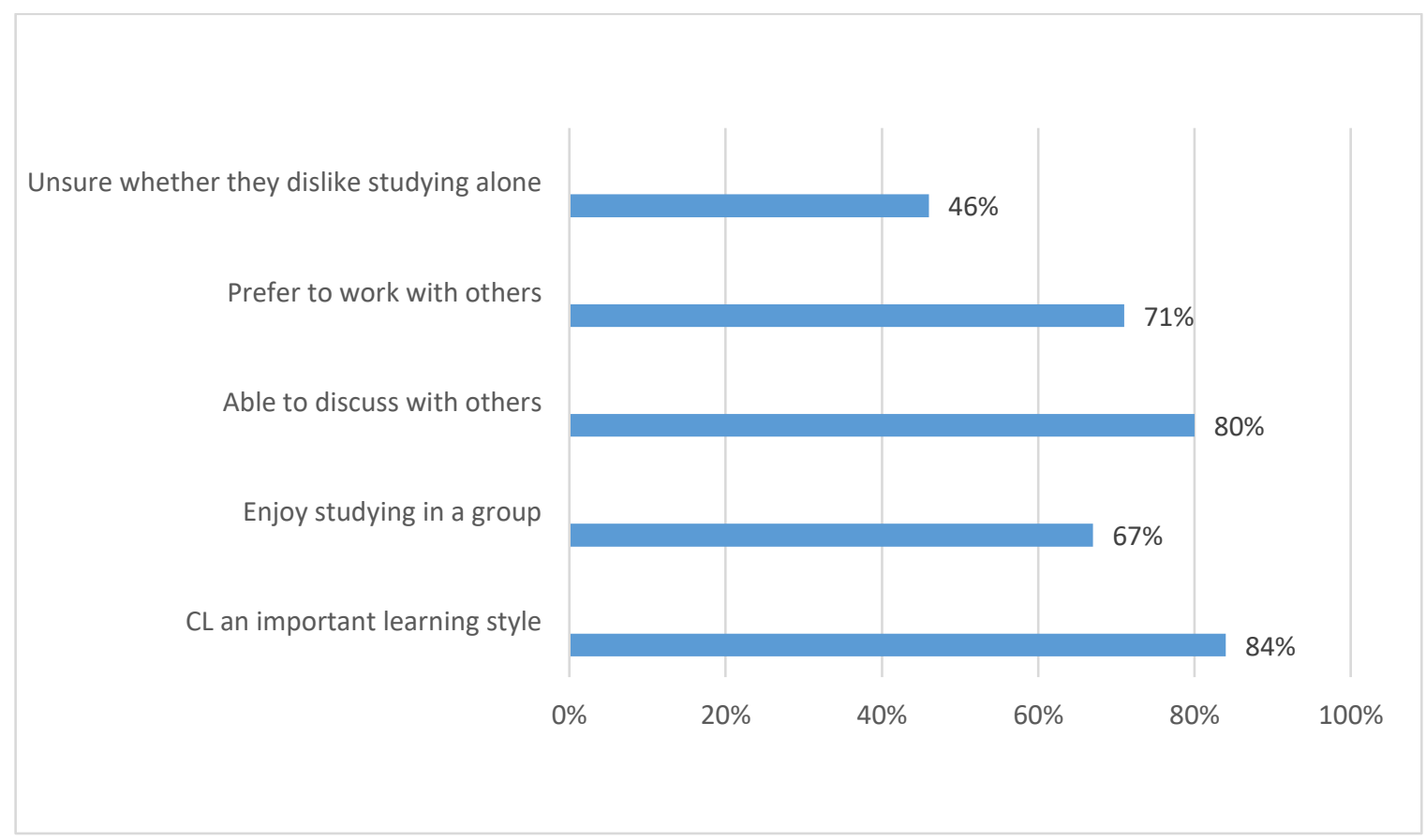

Figure 1: The Students' Attitudes towards Collaborative Learning 


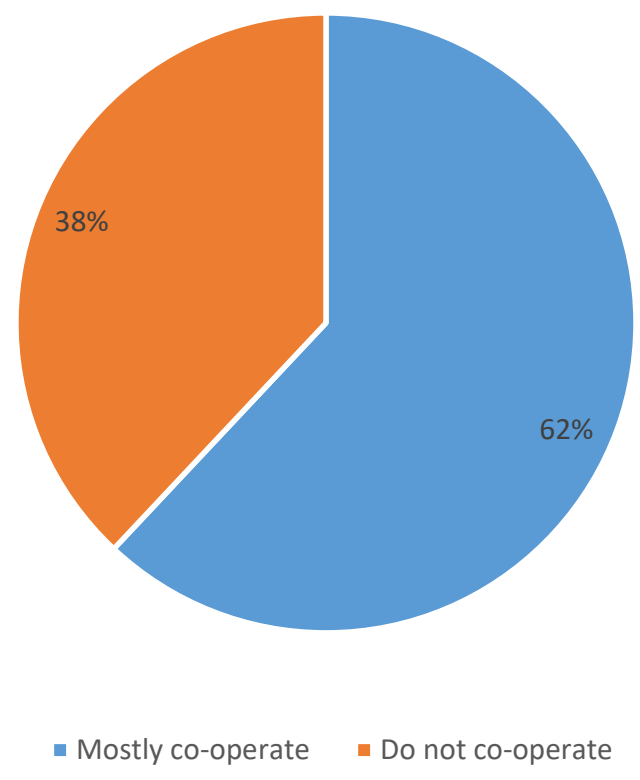

Figure 2: Students That Co-Operate in The Classroom

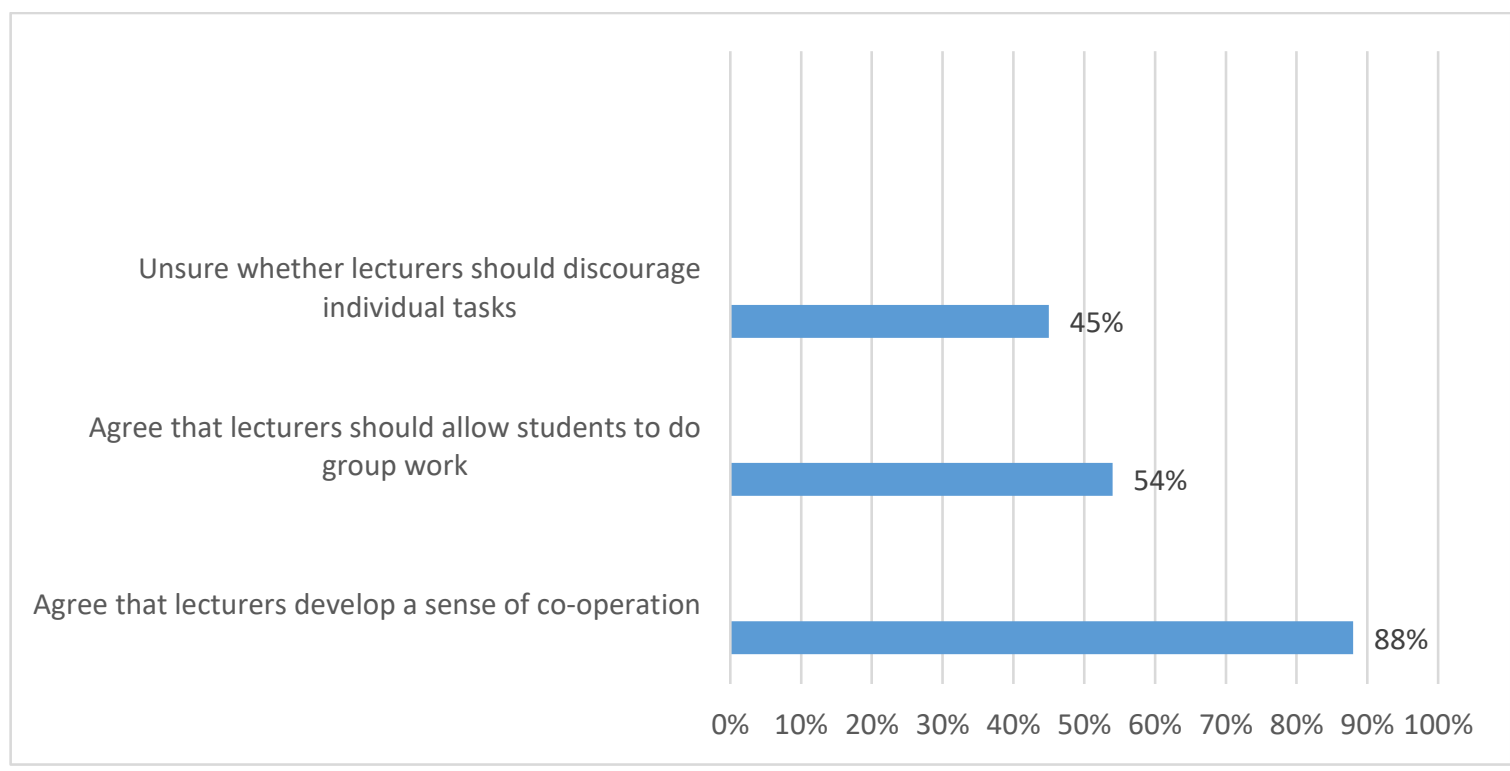

Figure 3: Students' Perception on the Role of Lecturers in Collaborative Learning 


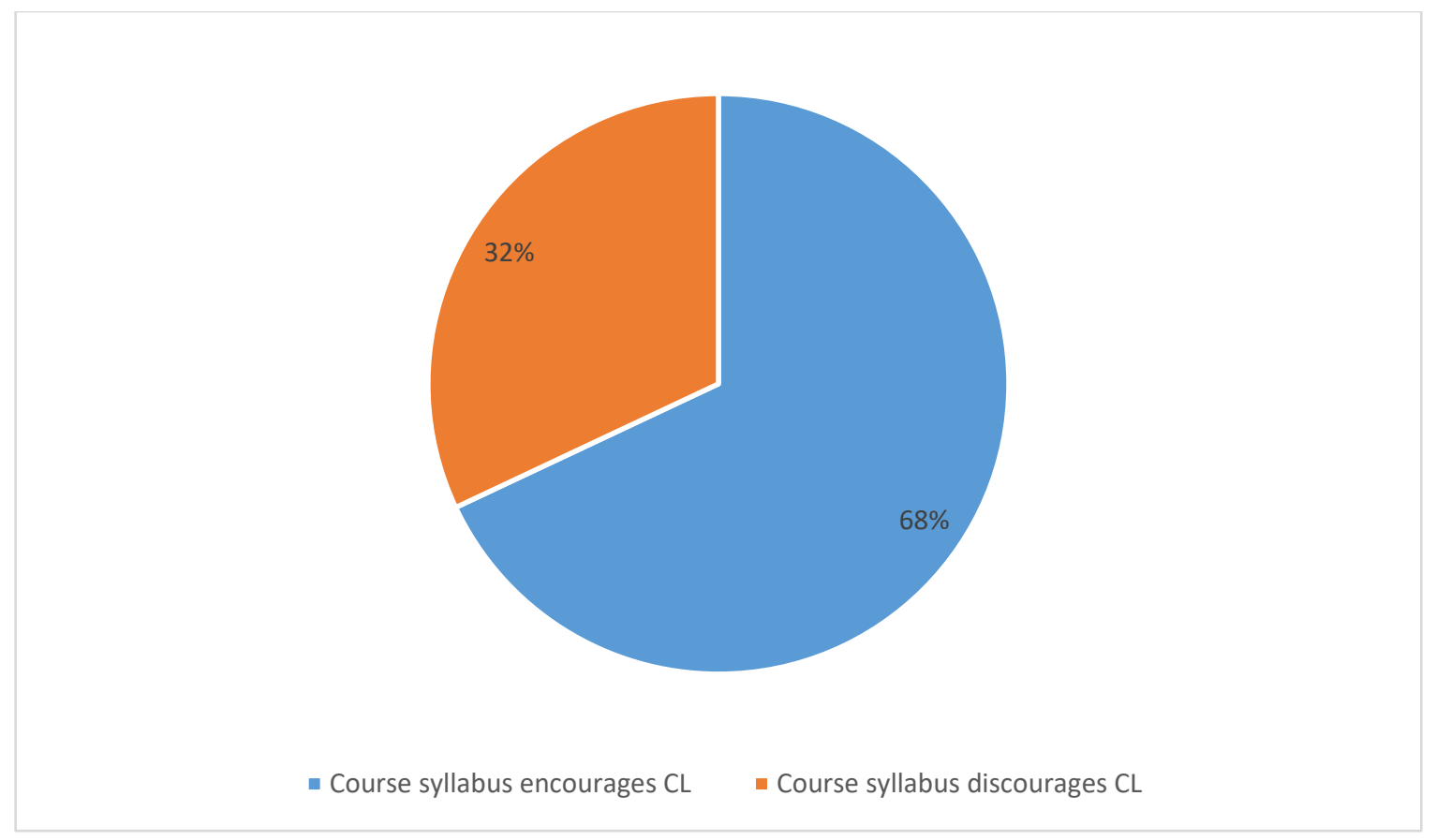

Figure 4: The Role of the Course Syllabus in relation to Collaborative Learning.

\section{Conclusion}

Collaborative learning has been shown to produce positive results especially to the students. Several studies have shown that this learning method in particular brings numerous benefits. Therefore, it is crucial that measures are taken to incorporate the collaborative learning method in the classroom.

\section{References}

Abdu R., De-Groot, R., \& R., Drachman. 2012. Teachers' role in computer supported collaborative learning. www.openu.ac.i1/.../a-Abdu-etal-102_eng.pdf 16 April 2018

Adecco Staffing US, 2016. Lack of soft skills negatively impacts today's U.S. workforce. http://www.adeccousa.com/about/press/Pages/20130930-lack-of-soft-skills-negatively impacts-todays-us-workforce.aspx 12 April 2018

Alsever, J., Hempel, J., Taylor, A. III, \& Roberts, D. 2014. 6 great teams that take care of business http://fortune.com/2014/04/10/6-great-teams-that-take-care-of-business/ 11 April 2018

Brown,B.L. (2001) Web-based training. ERIC Digest. (online digest) http: www.ericdigests.org/2001-2/training.html 18 August 2018

Brufee, K. (2000) Collaborative learning: higher education, interdependence, and the authority of knowledge (2nd edition) Baltimore: John Hopkins University Press.

Cabrera, A.F, Colbeck, C.L, \& Terenzini, P.T. (2001) Developing performance indicators for assessing classroom teaching practices and student learning. Research in Higher Education, 2(3), 327-352.

Chalmers, D. 2008. Teaching and learning quality indicators in Australian universities Outcomes of higher education: quality relevance and impact. IMHE Programme On Institutional Management in Higher Education. Paris, France.8-10 Sept 2008. (online report) http://www.oecd.org/dataoecd/4/40/41216416.pdf 22 August 2018. 
Daradoumis,T, \& Marques, J.M. 2000. A methodological approach to networked collaborative learning: design and pedagogy issues. (online report) T.Daradoumis...-...Conference on Networked Learning...,2000-uoc.edu 18 May 2018

Gillies, R.M. \& Boyle, M. 2010. Teachers' reflections on cooperative learning: Issues of implementation. Teaching \& Teacher Education. 26, 933-940 www.elsevier.com/locate/tate 16 April 2018

Hacker D.J. and Niederhauser, D.S. 2000. Promoting deep and durable learning in the online classroom. In R. E. Weiss, D. S. Knowlton, \& B. W. Speck (Eds.), "Principles of effective teaching in the online classroom" (pp.53-64). San Francisco: Jossey-Bass. [ED 447767]

Hedge, T. 2000. Teaching and learning in the language classroom. Oxford: Oxford University Press

Khairiyah Mohd Yusof \& Mimi Haryani Hassim. 2003. Cooperative Learning in Process Dynamics and Control Course for Undergraduates Chemical Engineering Students. Universiti Teknologi Malaysia Skudai: 7th Triennial AEESEAP Conference Proceedings.

Layman,L. 2006. Changing students' perceptions: an analysis of the supplementary benefits of collaborative software development. (online report)

L.Layman-2006-computer.org 12 July 2018

McCabe, R. H. 2003. Yes, we can! A community college guide for developing America's underprepared. United States of America: League for Innovation in the Community College and American Association of Community Colleges.

Minkler, J. E. 2002. ERIC review: Learning communities at the community college. Community College Review, 30(3), 46-63. (online digest) http://wilsontxt.hwsilson.com/pdffull/03788/W6B9M/VSI.pdf 17 June 2018

Ngeow, K.K. 2004. Learning through discussion: designing tasks for critical inquiry and reflective learning. ERIC Digest (online digest) http://www.ericdigests.org/20041/tasks.htm 20 July 20158

Oxford dictionary. 2010. dictionary) http://www.oxforddictionaries.com/view/entry/m_en_gb0162350\#m_en_gb0162350 10 April 2018

Oxford reference. 2016. (online reference) http://www.oxfordreference.com/view/10.1093/oi/authority.20110803095920725 14 April 2018

Roberts, T.S. 2005. Computer-supported collaborative learning in higher education. (online report) TS Roberts...-2005-gymnasium441.ru 21 March 2018

Russo, K. 2013. Hard skills vs. soft skills: what they mean to your job search and the weight they carry with HR. http://www.huffingtonpost.com/kristi-russo/hardskills-vs.softskill b8341566.html 13 April 2018

Ryan, L. 2019. 12 qualities employers look for when they're hiring. https://www.forbes.com/sites/lizryan/2016/03/02/12-qualities-employers-look-forwhen-theyre-hiring/\#4c1b24442c24 13 May 2019

Seng,T.H. 2006. Cooperative learning and achievement in English language acquisition in a literature class in a secondary school. (online database) eprints.utm.my/6550/1/tokhoonsengmp04... 24 July 2018

Sonmez, D, \& Lee, H. 2003. Problem-based learning in science. ERIC Digest. (online digest) http://www.ericdigests.org/2004-3/science.html 21 May 2018

Stahl,G., Koschmann,T., \& Suthers, D. 2006. Computer-supported collaborative Learning. In R.K. Sawyer (Ed.), Cambridge handbook of the learning Sciences (pp.409-425). Cambridge, UK: Cambridge University Press. 
Tinto,V. \& Pusser, B. 2006. Moving from theory to action: building a model of institutional action for student success. National Postsecondary Education Cooperative NPEC (online report) http://web.ewu.edu/groups/academicaffairs/IR/NPEC_5_Tinto_Pusser_Report.pdf 20 May 2018

Van Boxtel, C, Van der Linden, J \& Kanselaar,G. 2000. Collaborative learning tasks and the elaboration of conceptual knowledge. (online magazine) www.elsevier.com/locate/learninstruc 11 April 2018

Wilmer, E. 2009. The influence of learning communities on the interaction levels of developmental English students. Inquiry, Vol 14, No 1, Spring 2009, 55-67 (online magazine) www.vccaedu.org/inquiry-sprin... 12 April 2018

Wilmer, E. 2008. Student support services for the underprepared students. Inquiry. Vol.13, No.1, Spring 2008, 5-19 (online magazine) www.vccaedu.org/inquiry/inquiry-sprin... 20 April 2018 